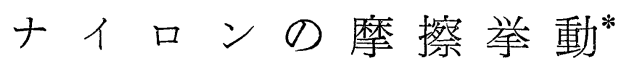

新 保 正 樹** 越 智 光一***
伊 藤 和 平***佐 々 木勝美***

\title{
Frictional Behavior of Nylons
}

by

\author{
Masaki Shimbo, Mitsukazu OchI, Kazuhira ITo and Katsumi SASAKI \\ (Faculty of Engineering, Kansai University, Suita)
}

Frictional behaviors of Nylons having different chemical structures were followed by observing the change of frictional coefficient in the glassy, transition and melt-flow regions of the system.

In the glassy region, a constant value of frictional coefficient was observed in spite of the variation in contact pressure. Only shearing fracture was observed in the region.

A good correlation was observed between the frictional coefficient and shearing modulus of elasticity or hardness of Nylons.

In the transition region, the maximum value of frictional coefficient was observed at $T_{g}$ and $T_{m}$. Stick and slip behavior was also observed in the region.

A good correlation was observed between the maximum values of frictional coefficient and damping. Orientation of Nylon layer was also observed in the region.

キー・ワード : 摩擦挙動, 摩擦係数, 動力学的性質, ナイロン

(Received May 28, 1977)

\section{1 緒言}

高分子の摩擦については応用に関する研究が压倒的 に多いが，摩擦機構の究明には Bowden, Tabor ら以 降半球スライダーを用いる方法がその主流をなしてい る.

しかし実際の摩擦は平面もしくは一定の曲率半径を もつ湾曲面で行われるのが普通である.したがって半 球状スライダーを用いる方法がこのような平面または 曲面の摩擦を研究するのに最もよい方法とは考光難い.

高分子の摩擦面を観察すると必ず破壞, 変形もしく は流動などの痕跡が認められる.乙たがって高分子の 摩擦を単なる表面現象として扱らのは不充分で, 高分 子層内部に和よぶ破壞, 変形もしくは流動などを考え るべきことが推定される.

在来高分子の摩擦と固体物性との相関を扱ったもの にはFlom による転り摩擦と動力学的性質の相関や, Bartenev, Vinogradov らによる融点と摩擦挙動に関 する研究などがある. しかし後者は融点で摩擦係数の 極大值が現れるとしているが，実測值には大きなズレ が認められ，な特討の余地が多い。

筆者らは前報で硬化度を異にする熱硬化性樹脂の平 面摩擦を調べ，摩擦挙動と動力学的性質の間によい相

* 原稿受理 昭和 52 年 5 月 28 日

** 正会員 関西大学工学部 吹田市千里山東

*** 関西大学工学部 吹田市千里山東
関があることを示した。

本報では熱可塑性樹脂のらら高度結晶性をもつナイ ロンと金属との平面摩擦を追跡し, 摩擦挙動と動力学 的性質を中心とする固体物性との相関を明らかにしよ らとした。

\section{2 実}

験

実験装置には Fig. 1 (A) に示す平面型摩擦試験機を 用いた。即ら水平に拈いた高分子試料 (Fig.1-(B), Fig.1-(A)4）の上をモーター（Fig. 1-(A)7）によって駆 動されるステンレス鋼製の摩擦子 (Fig. 1-(C), Fig. 1(A)5）の下面が接触しながら回転する.このよらな回 転円盤状摩擦子の形状之摩擦の関係は筆者の一人が検 討を行った.

摩擦の測定にはロードセルと電磁オシログラフを用 い, その值から摩擦係数と摩擦トルクを求めた. 測定 条件の範囲は滑走速度 : $0.5 \sim 60 \mathrm{~cm} / \mathrm{sec}$, 荷重 : 2 $45 \mathrm{~kg} / \mathrm{cm}^{2}$, 温度 : 室温 $300^{\circ} \mathrm{C}$ と，ふ九团気温度を 上昇させるときの昇温速度は $0.5^{\circ} \mathrm{C} / \mathrm{min}$ とした。 金属試料は18-8ステンレススチール (SUS-304, 日 本治金) とし，高分子試料は Table I に示すナイロ ン 6 (CM 1017, 東洋レーヨン), ナイロン6/6（レオ ナ1200, 旭化成), ナイロン6/10 (CM 2001, 東洋レ ーヨン）执よびナイロン12（L1801，ダイセル）を用 いた．金属試料は図のごとく切削した後摩擦面を耐水 研摩紙 \#1000を゙用いて水砥ぎし, その表面あらさは 
(A) Testing apparatus
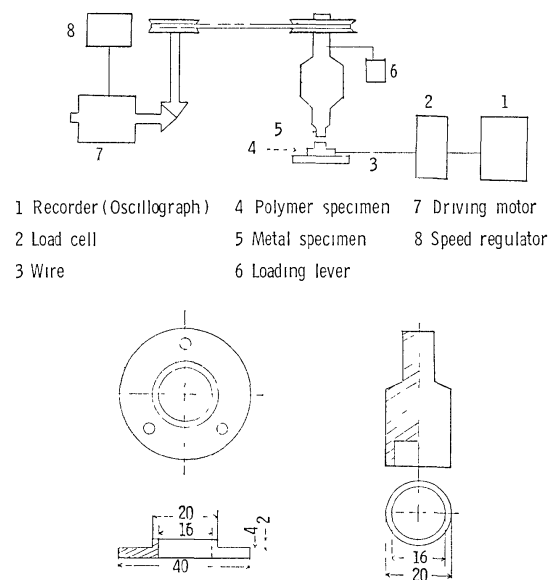

(B) Polymer specimen ( $\mathrm{mm}$ ) (D) Measurement of temperature

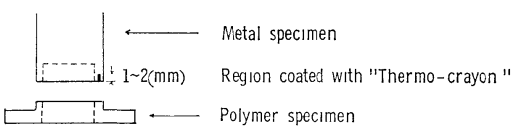

Fig. 1. Testing apparatus.

Table I. Some properties of Nylons.

\begin{tabular}{|c|c|c|c|c|}
\hline Properties & Nylon 12 & Nylon $6 / 10$ & Nylon 6 & Nylon 6/6 \\
\hline $\begin{array}{c}\text { Molecular } \\
\text { weight }\end{array}$ & 13600 & 13400 & 31000 & 56000 \\
\hline $\begin{array}{r}\text { Crystallinity } \\
(\%)\end{array}$ & 270 & 21.2 & 33.1 & 362 \\
\hline Density $\left(\mathrm{g} / \mathrm{cm}^{3}\right)$ & 1.02 & 1.06 & 1.14 & 1. 14 \\
\hline $\begin{array}{r}\text { Shear strength } \\
\left(\mathrm{kg} / \mathrm{cm}^{2}\right)\end{array}$ & 330 & 350 & 570 & 680 \\
\hline$T_{g}\left({ }^{\circ} \mathrm{C}\right)$ & 45 & 50 & 55 & 69 \\
\hline$\underset{\text { Hardness }}{T_{m}\left({ }^{\circ} \mathrm{C}\right)}$ & $182 \sim 183$ & $214 \sim 215$ & $223 \sim 224$ & $255 \sim 256$ \\
\hline $\begin{array}{c}\text { (Shore } D \\
\text { scale) }\end{array}$ & 59 & 60 & 63 & 69 \\
\hline
\end{tabular}

Fig.7-I に示した. 高分子試料は図のごとき寸度に切 削後そのまま測定試料とし, 測定の度ごとに新しい試 料を用いた。

試料の表面あらさは触針法による表面形状測定機に より速度 $0.1 \mathrm{~mm} / \mathrm{sec}$, 圧力 $0.5 \mathrm{~g}$ で測定した. 触針 尖端半径は $4 \pm 1 \mu$ である. 高分子の動力学的性質は ねじれ振子型粘弾性測定装置(レスカ)により周波数 1 $\mathrm{Hz}$, 昇温速度 $1^{\circ} \mathrm{C} / \mathrm{min}$ で測定し, この值から融点 $T_{m}$ とガラス転移温度 $T_{g}$ を求めた. 結晶度の測定はP Price および Müller, Pflüger によった. 摩擦面温度の測定 は極めて困難であるから 金属摩擦子下端 (Fig. 1-(C)) に $40^{\circ} \mathrm{C} \sim 175^{\circ} \mathrm{C}$ で変色するサーモクレヨン(紫山科学) 9 種により, 炎の変色から摩擦子温度を知り摩擦面温 度を測定しょうとした。

\section{3 結果および考察}

\section{$3 \cdot 1$ ガラス状領域の摩擦}

低速度 $(1 \mathrm{~cm} / \mathrm{sec})$ で摩擦発熱の少い状態のナイロ ンの摩擦を Fig. 2 に示した.

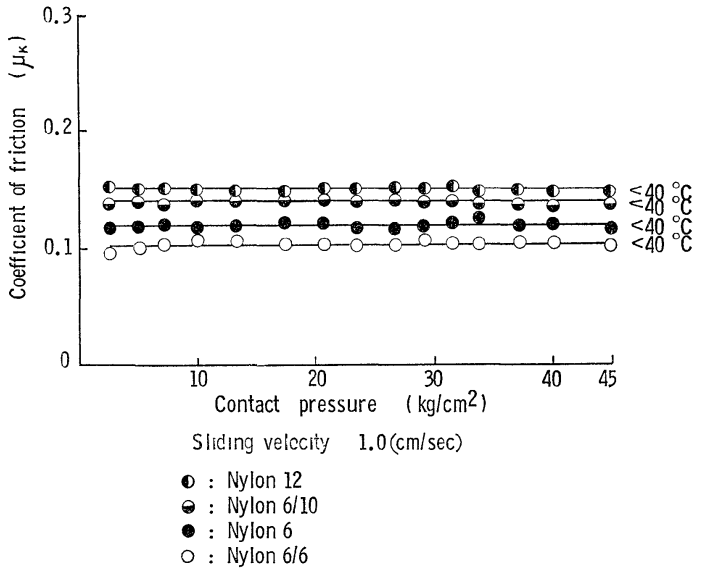

Fig. 2. Frictional properties of Nylons.

図のごとく 4 種のナイロンいずれも接触圧の変化 ( 2 $\left.\sim 45 \mathrm{~kg} / \mathrm{cm}^{2}\right)$ 飞もかかわらず動摩擦係数 $\mu_{K}$ は一定 值を示し, 摩擦子温度もすべて $40^{\circ} \mathrm{C}$ 以下を示した.

これら 4 種のナイロンのガラス転移温度 $T_{g}$ はいず れも $45^{\circ} \mathrm{C}$ 以上 (Table I) であることから, Fig. 2の摩 擦挙動はこれらナイロンのガラス状領域の摩擦と考党 られる.もちろんガラス状領域とはいえナイロン結晶 は存在する.この場合ナイロン表面はせん断破壊と考 穴られる状態で，ナイロンの金属への凝着が少量にす

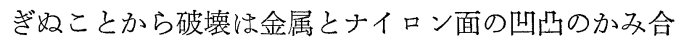
いによるせん断破壊と考光られる (Fig. 5-(B)).

\section{$3 \cdot 2$ 転移領域の摩擦}

速度を増加させ (1〜 60 cm/sec), 摩擦発熱を増加

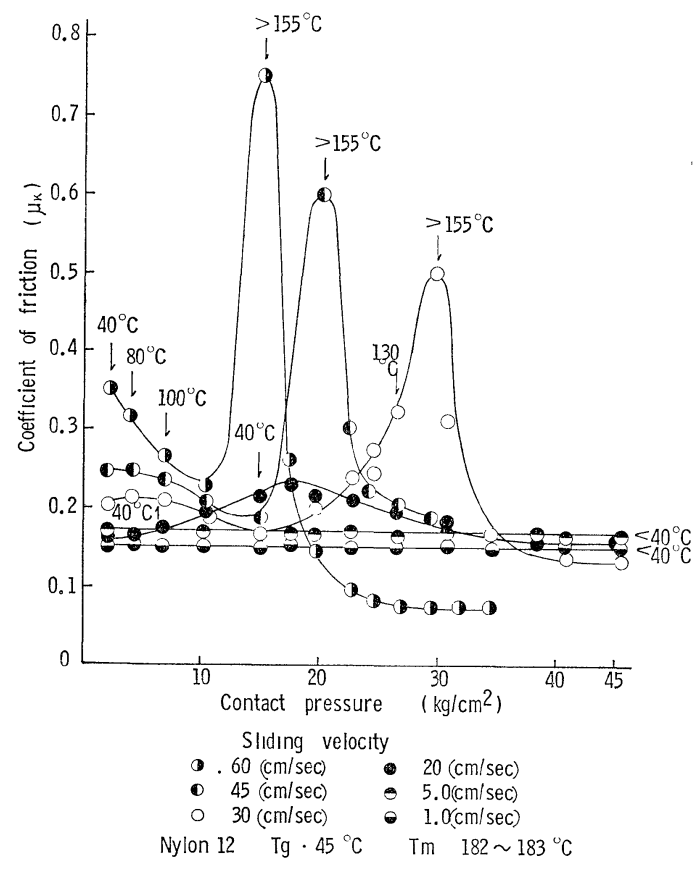

Fig. 3. Frictional properties of Nylon 12 . 
させたときのナイロン 12 の摩擦挙動を Fig. 3 に示し た。

最も速度の低い場合 $(1 \mathrm{~cm} / \mathrm{sec})$ には接触圧が変化 (2〜 45 kg/ $\left.\mathrm{cm}^{2}\right)$ しても $\mu_{K}$ は一定值を示し，摩擦子 温度も $40^{\circ} \mathrm{C}$ 以下であった. 速度をやや増加 $(5 \mathrm{~cm} / \mathrm{sec})$ してもこの傾向は変らず, 摩擦子温度も $40^{\circ} \mathrm{C}$ 以下であ ったが， $\mu_{K}$ は一定值のまま僅かに増大した。これら 二つの場合ともに摩擦子温度は $40^{\circ} \mathrm{C}$ 以下でガラス状領 域に相当し, ナイロン表面はせん断破壊と考学られる 状態であった. この場合の金属摩擦子へのナイロンの 付着量は少く, 主として金属とナイロン面の凹凸のか み合いによるせん断破壞と考光られる.

速度を順次増大させ $(20,30,45$ おる゙ $60 \mathrm{~cm} / \mathrm{sec})$, 摩擦発熱を増加させると $\mu_{K}$ が一定值を示す領域はみ られなくなり， $\mu_{K}$ には二つの極大值が現れるよらに みえる.これらのらら一つの極大值はやや不明りょら でピーク高さも低く, 摩擦子温度も低い.

これに対して他の極大值はピーク高さも高く, 摩擦 子温度も $155^{\circ} \mathrm{C}$ 越光る。 しかも速度増加とともにこ の極大值は大きくなり, かつ低接触圧側に移行する.

これらの挙動はナイロン 6，6/6 执よび 6/10 のい ずれについても共通であった（図省略).

筆者らは硬化度を異にする熱硬化性樹脂の摩擦で, $\mu_{K}$ の極大值はそれぞれの硬化物の $T_{g}$ で現れること を示した.

ナイロン 4 種の $T_{g}$ は Table I のごとく $45^{\circ} \sim 69^{\circ} \mathrm{C}$

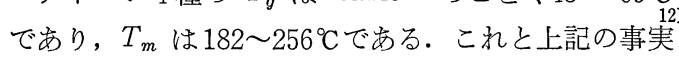
を考觉ると，ナイロンの $\mu_{K}$ の極大值はとれぞれの $T_{g}$ および $T_{m}$ で現れるのではないかと考えられる.この 推定については次節でのべる.

Fig. 3 の二つの $\mu_{K}$ の極大值を示す温度域では, 摩 擦力により接触面に沿って作用するせん断応力に直角 方向の波状痕跡が認められた（Fig.5-(C)，および (D)). 同時に摩擦トルクには脈動が現れ (Fig.8), 金属表面 へのナイロンの付着はほとんどみられず，この状態は “Stick and Slip”とよばれる凝着すべり現象に相当す ると考えられる．またせん断応力に直角方向の波状痕 跡も温度上昇に伴って軟化したナイロン面の上部が金 属面に凝着してナイロン層上面の変形を招いた後離脱 するために起るものと考えられる.

Fig. 3 の $\mu_{K}$ の大きな極大值は速度が増加すれば低 接触圧側に移行するが, そのピーク值よりも高接触圧 側で摩擦発熱の多い領域では $\mu_{K}$ は急低下し, この領 域では摩擦面には明りょうな流動痕跡が認められた (Fig. 5(E)).

\section{$3 \cdot 3$ ふん囲気温度の上昇に伴う摩擦挙動の変化}

前節の結果から $\mu_{K}$ の極大值はその $T_{g}$ または $T_{m}$ で現れるのではないかとの推定に導かれる.

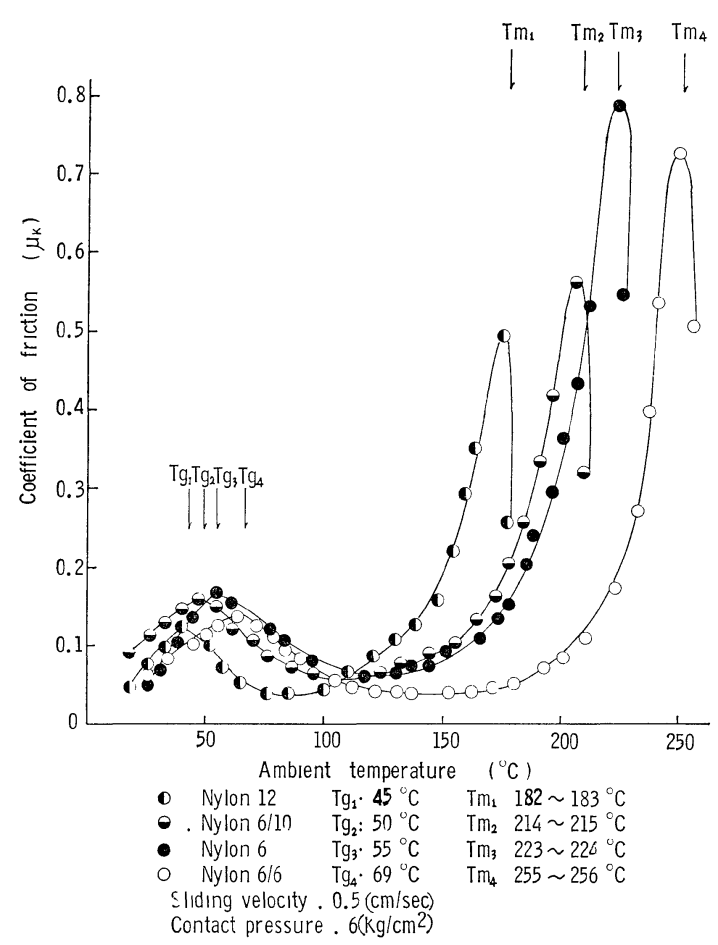

Fig. 4. Frictional properties of Nylons.

この推定を確かめるために低速 $(0.5 \mathrm{~cm} / \mathrm{sec})$ およ び低接触圧 $\left(6 \mathrm{~kg} / \mathrm{cm}^{2}\right)$ で摩擦発熱を極力抑制し， ふ ん囲気温度を上昇させたときのナイロン 4 種の $\mu_{K}$ の 温度分散を Fig. 4 に示した.

図のごとく各ナイロンについて $\mu_{K}$ にはそれぞれ二 つの極大值が観察される.

この $\mu_{K}$ の極大值をそれらナイロンの $T_{g}$ 特よび $T_{m}$ (Table I) と比較すると, この両者の温度差は大 部分が $2 \sim 3{ }^{\circ} \mathrm{C}$ 以内, 最大でも $5^{\circ} \mathrm{C}$ の範囲にすぎない. したがってナイロンの摩擦では $\mu_{K}$ の極大值は前報同 様それぞれの $T_{g}$ 抢よび $T_{m}$ で現れるとみてよいで あろら・

\section{$3 \cdot 4$ 摩擦面の観察}

ナイロンの摩擦挙動は前節までの結果から少くとも (1)カラス状領域の摩擦，（2)転移領域の摩擦 $\left(T_{g}\right.$ 域拈 よび $T_{m}$ 域) および(3)流動域の摩擦の 3 者を区分する ことができる. また $T_{g}$ 域と $T_{m}$ 域の間に摩擦係数 が極少を示す領域があるが，この領域での摩擦面はせ ん断破壞と考兄られる痕跡を示した.

これらの挙動と摩擦面の状態がどのよらな関係にあ るかを反射顕微鏡と偏光顕微鏡によって観察した.

Fig. 5 には反射顕微鏡による観察結果を示した.

摩擦前の試料では切削による条痕が認められ(Fig. 5 (A))，ガラス状領域の摩擦面にはせん断破壞痕跡が認 められた (Fig. 5(B)).

速度が上昇し, 摩擦発熱の増加した $T_{g}$ 域抒よび $T_{m}$ 


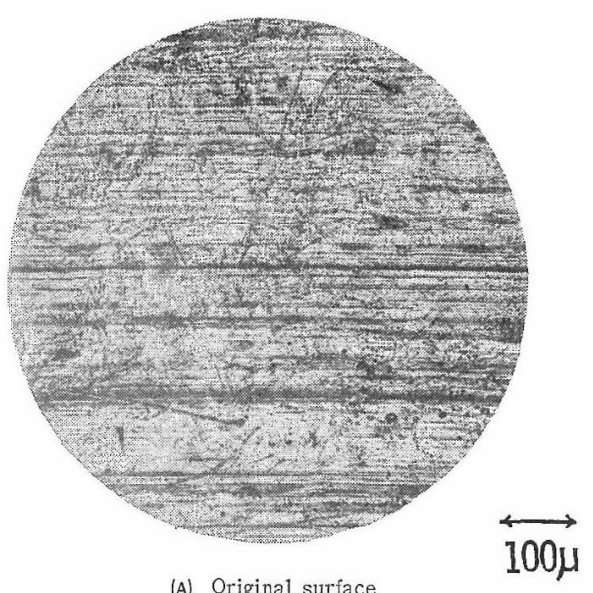

(A) Original surface

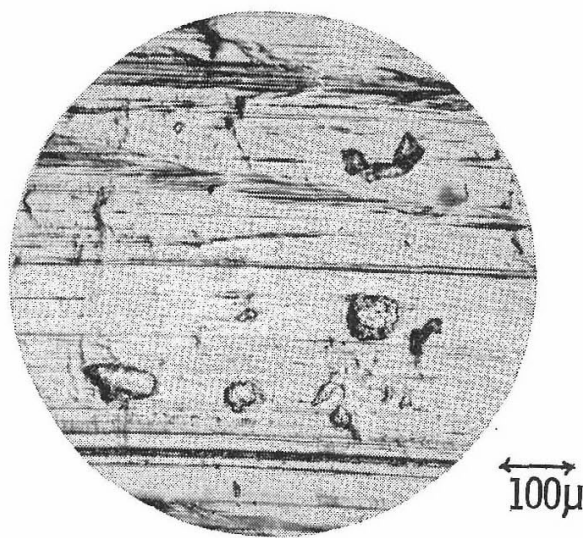

(B) Process of "Shearing"

Sliding velocity: $5(\mathrm{~cm} / \mathrm{sec})$

Contact pressure: $10\left(\mathrm{~kg} / \mathrm{cm}^{2}\right)$

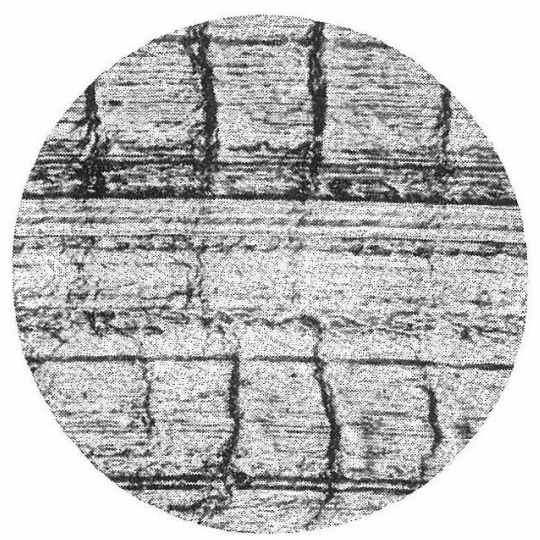

(C) Process of "Transition" at $T_{g}$ Sliding velocity: $20(\mathrm{~cm} / \mathrm{sec})$

Contact pressure: $17\left(\mathrm{~kg} / \mathrm{cm}^{2}\right)$

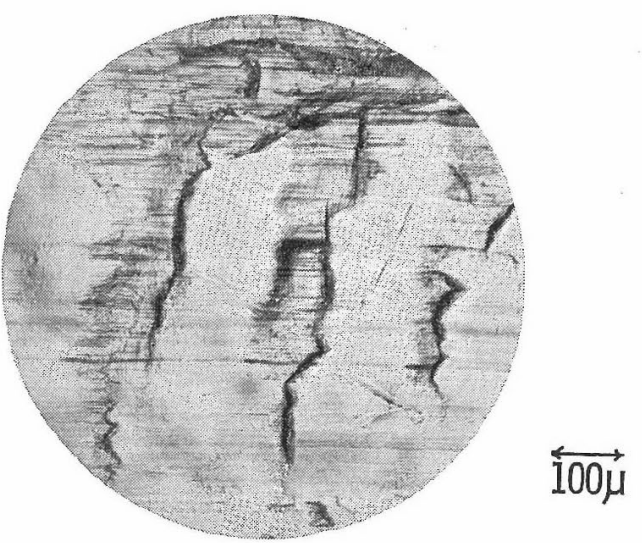

(D) Process of "Transition" at Tm Sliding velocity: $45(\mathrm{~cm} / \mathrm{sec})$ Contact pressure: $17\left(\mathrm{~kg} / \mathrm{cm}^{2}\right)$

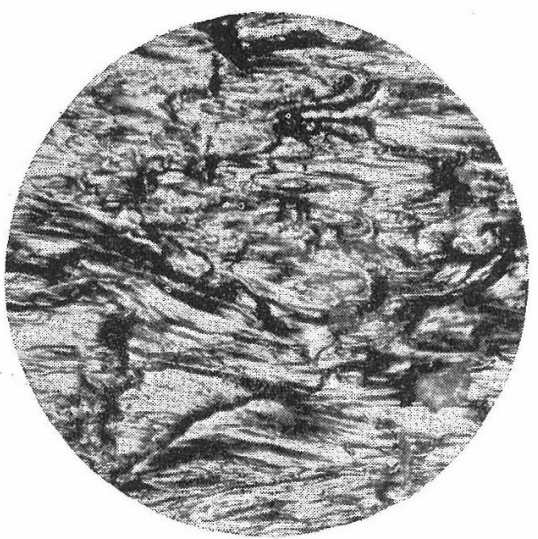

$\overleftrightarrow{100 \mu}$

(E) Process of "Melt flow"

Sliding velocity: $45(\mathrm{~cm} / \mathrm{sec})$

Contact pressure: $29\left(\mathrm{~kg} / \mathrm{cm}^{2}\right)$

Direction of sliding

Fig. 5. Frictional traces of Nylon 12 .

イロン面の相対的な移動に伴って破壊または変形を伴 ら㠜着すへり現象のためと考方られる。

速度やらん囲気温度が更に高くなれば $\mu_{K}$ は極大值 を示した後急低下する (Fig. 3，4)。この領域では摩

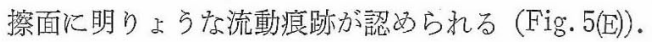

同様な観察をナイロン $6 ， 6 / 6$ ，および $6 / 10$ につい 


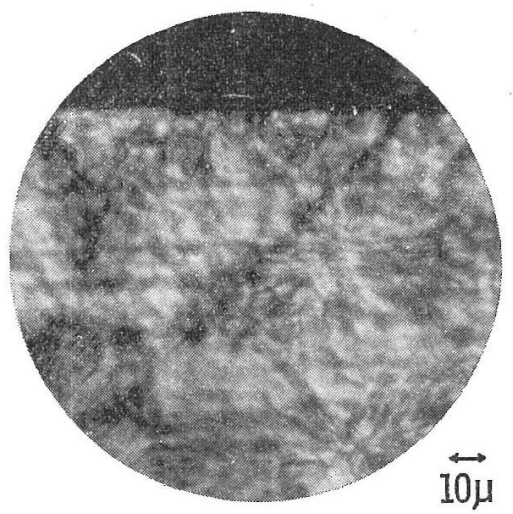

(A) Original scction

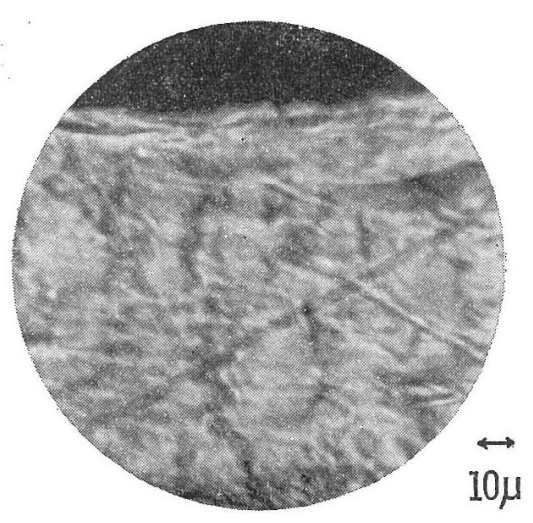

(B) Process of "Orientation"

Fig. 6. Cross section of Nylon 12.

て行ったが各段階に敊ける挙動はすべて同様であった (図省略).

つぎにナイロンの摩擦面をミクロトームで切断し,

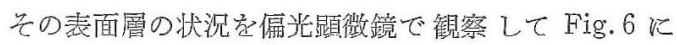
示した。

摩擦前のナイロンでは発達した球晶がその表面層に まで及んでいる (Fig.6(A))。これに対して転移領域の 摩擦ではナイロン表面から内部に約 $100 \mu$ にわたって 配向㤎認められ，球晶す破壊されている (Fig. 6(B)).

これはナイロン表面が金属面に㠜着され，摩擦面の せ九断応力によってその表面層が移動するために分子 鎖は配向し，球晶が破猿されるものと考光られる。

即ら転移領域の摩擦ではナイロン内部約 $100 \mu$ にわ たって摩擦の影響が現れるから,ナイロンの摩擦は表 面のみの現象として取扱らことは不充分で，摩擦をと の固体物珄との関連で扱うべさ根拠を示すとい党よう。

\section{$3 \cdot 5$ 表面あらさの測定}

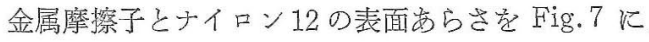
示した.

摩擦前のナイロン表面は切削による微細な粗面で方 るが (Fig.7(II)(A))，ガラス状領域の摩擦後の表面京 らさはやや増大寸る (Fig.7(II)(B))。これは表面にお

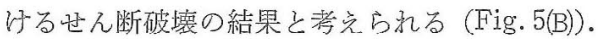

$T_{g}$ 域の摩擦後の表面埂に岁らくなり(Fig. 7(II) (C)), 粗面の山の数は減少する. $T_{m}$ 域の摩擦後もこ の傾向ば添ぼ同様であるが (Fig.7(II)(D)), 流動域の

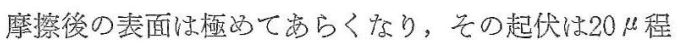
度に達した(Fig. 7(II)(E))。

同様な測定をナイロン $6 ， 6 / 6$ おる゙ $6 / 10$ について 行ったが各段階に和ける表面形状の傾问はすべて同様 であった(図省略)。

\section{$3 \cdot 6$ 摩擦トルクの測定}

電磁オシログラフによるナイロン12の摩擦トルクの 時間的変化を Fig. 8 に示した。

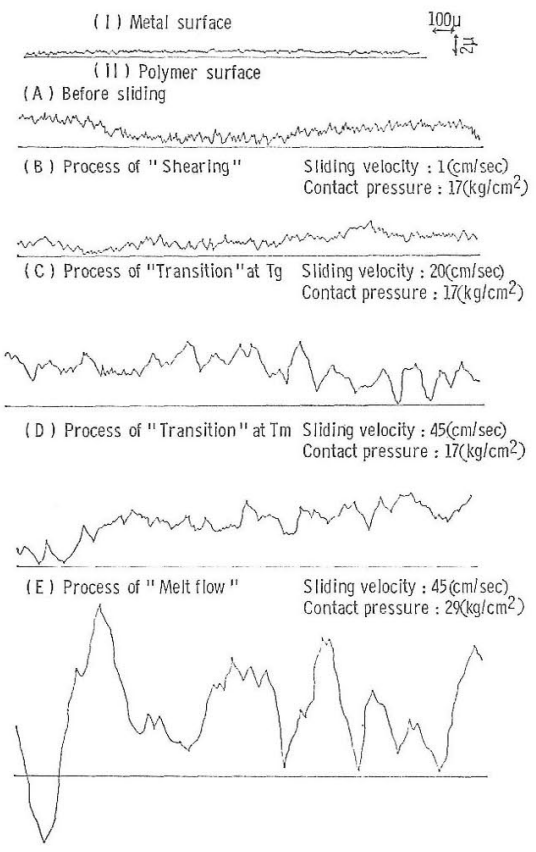

Fig. 7. Geometrical changes of metal and Nylon 12 surface.

ガラス状領域の摩擦ではトルク值も小さく，その变 動幅け極めて小さい.しかもトルク值は時間の経過に かかわらず一定值气示した (Fig.8(A)).

この㑯向はナイロン表面の粗面の山が金属と接触し (Fig.7)，絶光ず小面積のせん断破壤が繰返されるた め之考学られる(Fig. 5 (B)，8(A))。

$T_{\boldsymbol{g}}$ 域の摩擦ではトルク值は増大し, その变動幅む 大きくなる。しかこの変動状態はかなりの時間維持 されを(Fig.8(B)).

この状態はナイロン堆面の一部が金属面に㠜着し，

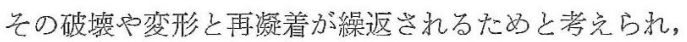
凝着すべり現象に該当すると考兑られる。

$T_{m}$ 域の摩擦ではトルク值は急上昗して極大值を示 

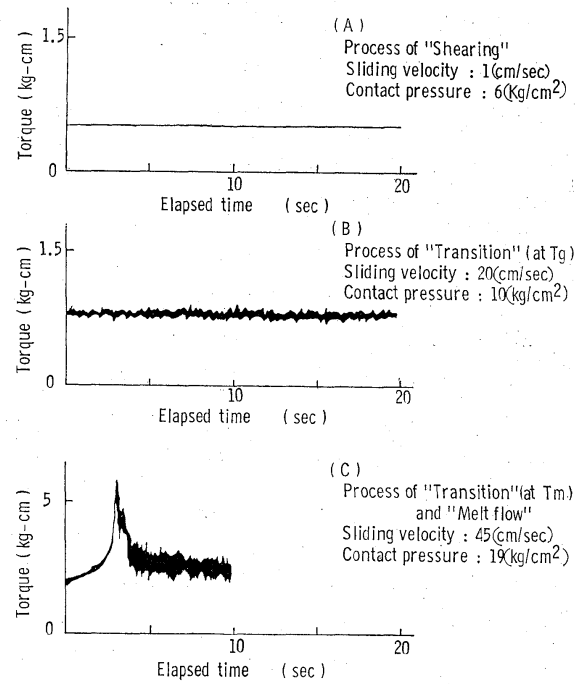

Fig. 8. Frictional characteristics of Nylon 12 .

した後に急低下する.この極大值を経た後のトルクの 変動幅は大きく, この状態の摩擦面には流動痕跡が認 められる (Fig.5(E), 7(II)(E), 8(C)).

これはナイロン表面が $T_{m}$ に達して $\mu_{K}$ の極大值 を示した後流動に移行する事実を説明する.

同様な測定をナイロン $6 ， 6 / 6$ 和よび 6/10について 行っても, 各段階における挙動はすべて同様であった (図省略).

\section{$3 \cdot 7$ 摩擦挙動と高分子物性}

Fig. 8 にはナイロンのガラス状領域に打ける $\mu_{K}$ の 一定值 (Fig. 2) とそのせん断弾性率の関係を示した.

図のごとく $\mu_{K}$ とせん断弾性率との間にはほぼ直線 関係が認められる.

同様にナイロンの $\mu_{K}$ の一定值 (Fig. 2) とその硬 さとの間にも同様な直線関係が認められた (図省略).

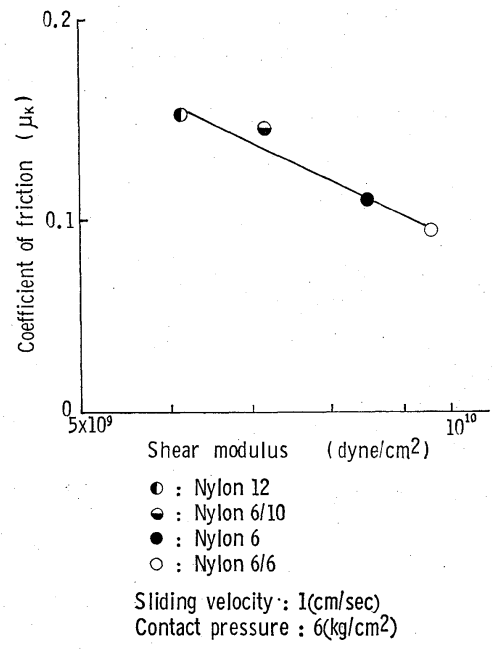

Fig. 9. $\mu_{\boldsymbol{K}}$ vs. shear modulus for Nylons.
切削仕上したナイロン表面は粗面で (Fig. 7(II)(A))， この粗面の山の頂点が金属面と接触する. この場合, 接触圧が一定ならばナイロンの弾性率またはかたさの 大きいものほど粗面の山の頂点は変形しにくく，金属 との接触面積は小さくなるはずである.

摩擦の測定ではナイロンと金属面は互いにせん断方 向に移動し，両者の接触面積が小さいほどせん断破壞 抵抗值は小さくなるはずである. 摩擦係数として測定 される值はこのせん断破壤抵抗值であるために, ナイ ロンの弾性率やかたさと $\mu_{K}$ の值 (Fig. 2) との間に 直線関係が成立するものと考光られる，事実，顕微鏡 観察の結果からも, 弾性率またはかたさの大さいナイ ロンほどせん断破壞をらける面積が小さい傾向が認め られる。

Fig. 10 には $T_{g}$ に和ける $\mu_{K \max }$ と $\tan \delta_{\max }$ との 関係を示した. $T_{g}$ では $\mu_{K}$ も $\tan \delta$ もともに極大值 を示し，両者の間に汪汸值線関係が認められる。

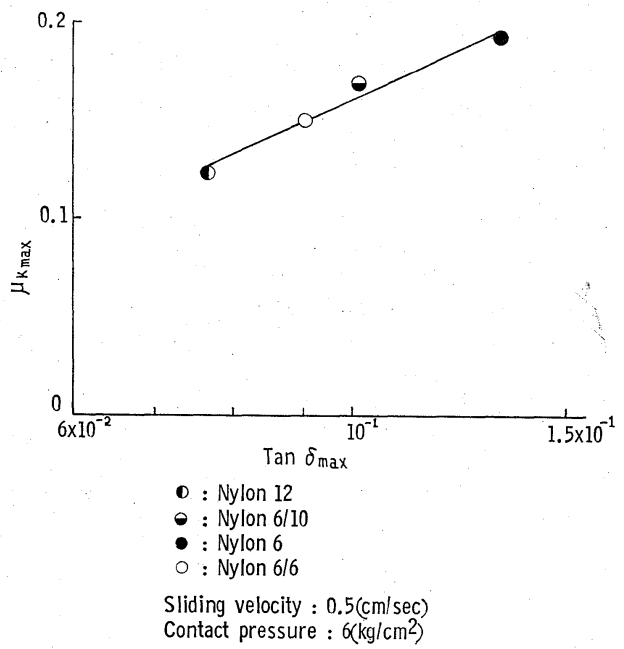

Fig. 10. $\mu_{K \max } v s . \tan \delta_{\max }$ for Nylons at glass transition temperature.

即らガラス転移温度での $\mu_{K}$ はその減衰の大きさに 支配されることになる。いかえれば力学的エネルギ が最も多く熱に変換される点で動摩擦係数は極大值を とるということもできよう.

\section{4 結 論}

結晶性高分子の例としてナイロン類を選び，速度， 接触圧特よびろん囲気温度をかえてその摩擦挙動を追 跡した.

これらの結果をナイロンの動力学的性質和よび力学 的性質と比較したほか, 表面めらさと摩擦面の顕微鏡 観察の結果と対照し, 摩擦挙動とこれら諸性質の関係 を検討した。

その結果，ナイロンと金属との平面摩擦挙動を次の 
ごとくなとめてょいであろう.

(1) ガラス状領域の摩擦

低速度で摩擦発熱が少く,ふん囲気温度が低く, ナ イロンが $T_{g}$ 以下の温度に怙ける摩擦はガラス状領域 の摩擦と考克られる.

この領域では動摩擦係数は接触圧の変化にかかわら ず一定值を示し，摩擦面にはせん断破壊痕跡が認めら れた。

この領域に执ける動摩擦係数はナイロンの弾性率も しくはかたさとよい相関を示した.

これはナイロンの弾性率やかたさがその粗面頂点と 金属との接触面積を支配し，この接触面積の大小がせ え断破壞抵抗值, 即ち摩擦係数を支配するためと考兄 られる.

(2) 転移領域の摩擦

温度が上昇して摩擦発熱が増加するか，もしくはふ 儿团気温度が上昇してナイロンがその転移温度達す ると, 摩擦係数には極大值が現れ, 凝着すべり現象が 観察される.

この挙動はガラス転移温度持よび融点の双方で観察 され，摩擦係数の極大值を示す温度はそれぞれのナイ ロンのガラス転移温度就よび融点に一致するものと考 えられる。

ガラス転移温度に括ける摩擦係数の極大值と減衰の 極大值との間にはよい相関が認められた。

さらに転移領域の摩擦ではナイロン表面層約 $100 \mu$ にわたって配向と球晶の破壊が認められた.

これらの事実はナイロンの摩擦は単なる表面現象と して扱らだけでは不充分で, その固体物性との相関に
おいて論ずべきことを示している。

（3）流動域の摩擦

速度上昇に伴う摩擦発熱の増加, もしくはふん囲気 温度の上昇に伴ってナイロン表面には流動痕跡が認め られ, 表面層の溶融流動が認められた.

\section{参考文 献}

1) Bowden, F. D., and D. Tabor, "The Friction and Lubrication of Solid", (1950).

2) Bowden, F. D., and D. Tabor, "The Friction and Lubrication of Solid II", (1964).

3) Tabor, D., and C. M. Pooley, Proc. Roy. Soc., A 329, 251 (1972).

4) Tabor, D., and D. E. Weyne, Wear 4, 391 (1961).

5) Flom, D. G., J. Appl. Phys., 31, 306 (1960).

6) Flom, D. G., J. Appl. Phys., 32, 1426 (1961).

7) Bartenev, G. M., and A. J. Elkin, J. Polym. Sci., Part C, 16, 1673 (1967).

8) Vinogradov, G. V., and G. M. Bartenev, Brit. J. Appl. Phys. 2, 1687 (1968).

9) Bartenev, G. M., A. J. Yel'kin, and V. N. Nikolaev, Vysokomol soyed., A 10, 808 (1968).

10) Vinogradov, G. V., Yu. G. Yanovsky, E. I. Frenkin, Brit. J. Appl. Phys., 18, 1141 (1967).

11) Vinogradov, G. V., G. M. Bartenev, A. I. El'kin, and V.N. Mikh'aylov Wear 10, 213 (1970).

12）新保正樹, 水本康博, 越智光一, 高分子学会論文集, $\mathbf{3 2}$, 465 (1975).

13）新保正樹, 雪水, 21, 139 (1959).

14) Price, P., J. Chem. Phys., 19, 973 (1951).

15) Müller, A., and R. Pflüger, Plastics 24, 350 (1959). 